\title{
Erratum to: Disaggregation Modelling of Annual Flows into Daily Streamflows Using a New Approach of the Method of Fragments
}

\author{
Maria Manuela Portela ${ }^{1}$ Artur Tiago Silva ${ }^{1}$
}

Published online: 26 August 2016

(C) Springer Science+Business Media Dordrecht 2016

\section{Erratum to: Water Resour Manage}

DOI 10.1007/s11269-016-1402-y

Due to an oversight, equations 4 and 5 were wrongly captured in the published online pdf version. The correct presentation for equations 4 and 5 are shown below.

$$
\begin{gathered}
] \overline{\widehat{\theta}}-z_{1-\alpha / 2} s_{\overparen{\theta}} ; \quad \overline{\widehat{\theta}}+z_{1-\alpha / 2} s_{\overparen{\theta}}[ \\
\theta \notin] \overline{\widehat{\theta}}-z_{1-\alpha / 2} s_{\overparen{\theta}} ; \quad \overline{\widehat{\theta}}+z_{1-\alpha / 2} s_{\overparen{\theta}}[
\end{gathered}
$$

The online version of the original article can be found at http://dx.doi.org/10.1007/s11269-016-1402-y.

Maria Manuela Portela

maria.manuela.portela@tecnico.ulisboa.pt

1 CEris, Instituto Superior Técnico, Universidade de Lisboa, Lisbon, Portugal 